\title{
Crystal Structures of two Triazole Derivatives
}

P. Ambalavanan , K. Palani , M. N. Ponnuswamy , R. A. Thirumuruhan , H. S. Yathirajan , B. Prabhuswamy , C. R. Raju , P. Nagaraja \& K. N. Mohana

To cite this article: P. Ambalavanan , K. Palani , M. N. Ponnuswamy , R. A. Thirumuruhan , H. S. Yathirajan , B. Prabhuswamy , C. R. Raju , P. Nagaraja \& K. N. Mohana (2003) Crystal Structures of two Triazole Derivatives, Molecular Crystals and Liquid Crystals, 393:1, 67-73, DOI: 10.1080/10587250307068

To link to this article: https://doi.org/10.1080/10587250307068

曲 Published online: 18 Oct 2010.

Submit your article to this journal

Џ Article views: 44

Q View related articles ¿

4 Citing articles: 5 View citing articles 진 


\title{
CRYSTAL STRUCTURES OF TWO TRIAZOLE DERIVATIVES
}

\author{
P. Ambalavanan, K. Palani, M. N. Ponnuswamy, \\ and R. A. Thirumuruhan \\ Department of Crystallography and Biophysics, \\ University of Madras, Guindy Campus, \\ Chennai-600 025, India \\ H. S. Yathirajan, B. Prabhuswamy, C. R. Raju, P. Nagaraja, \\ and $K$. N. Mohana \\ Department of Studies in Chemistry, University of Mysore, \\ Manasagangotri, Mysore-570 006, India
}

\begin{abstract}
3-Phenyl-4-amino-5-mercapto-1,2,4-triazole(PAMT), $C_{8} H_{8} N_{4} S, \quad$ F.W. $=192.24$, triclinic, $P \overline{1}, a=6.1698(3) \AA, b=7.1765(1) \AA, \quad c=9.9894(3) \AA, \alpha=81.87(1)^{\circ}$, $\beta=84.97(2)^{\circ}, \quad \gamma=78.81(2)^{\circ}, \quad V=428.72(3) \AA^{3}, \quad Z=2, \quad D_{\text {cal }}=1.489 \mathrm{Mgm}^{-3}$, $\mu=0.330 \mathrm{~mm}^{-1}, F_{O 00}=200, \lambda(M o K \alpha)=0.71073 \AA$, final $R 1$ and $w R 2$ are 0.0871 and 0.2170, respectively. 3-(4-Methylphenyl)-4-amino-5-mercapto-1,2,4-triazole (MAMT), $C_{9} H_{10} N_{4} S, F . W .=206.27$, triclinic, $P \overline{1}, a=5.996(1) \AA, b=7.582(2) \AA$, $c=11.143(1) \AA, \quad \alpha=73.16(1)^{\circ}, \quad \beta=89.65(2)^{\circ}, \quad \gamma=87.88(1)^{\circ}, \quad V=484.52(3) \AA^{3}$, $Z=2, D_{\text {cal }}=1.414 \mathrm{Mgm}^{-3}, \mu=2.674 \mathrm{~mm}^{-1}, F_{\text {ooo }}=216, \lambda(\mathrm{CuK \alpha})=1.5418 \AA$, final $R 1$ and $w R 2$ are 0.0656 and 0.1820 , respectively. In both of the molecules the triazole rings are planar and oriented at angles of $5.7(1)^{\circ}$ and $1.4(2)^{\circ}$ with the respective phenyl rings in MAMT and PAMT. The molecules in the unit cell are stabilized by $N-H \ldots N$ type hydrogen bonds in addition to van der Waals forces.
\end{abstract}

Keywords: crystal structure; conformation; hydrogen bonding; PAMT; MAMT

\section{INTRODUCTION}

Compounds of 1,2,4-triazole derivatives are found to be associated with diverse pharmacological activity. Recently, some new triazole derivatives have been synthesized as possible anticonvulsants, antidepressants,

P. Ambalavanan would like to thank UGC for providing FDP under IX plan period and also Commissioner of Collegiate Education, Chennai-600 006 for giving permission to carry out the research work in the Department of Crystallography and Biophysics, University of Madras. 
tranquilizers, and plant-growth regulators [1-3]. Some of the iron (II) complexes containing substituted 1,2,4-triazole ligands are spin-crossover materials, which could be used as molecular-based memory devices, displays, and optical switches [4, 5]. The 1,2,4-triazole nucleus has recently been incorporated into a wide variety of therapeutically interesting drugs [6], including H1/H2 histamine receptor blocker, cholinesterase active agents, CNS stimulants, antianxiety agents, and sedatives.

Substituted 1,2,4-triazoles have been actively studied as bridging ligands coordinating through their vicinal $\mathrm{N}$ atoms. The complexes containing 1,2,4-triazole ligands possess specific magnetic properties [7-9]. On the other hand, some of the 1,2,4-triazole derivatives have anti-inflammatory activities [10] and some are antifungal agents [11].

Bhargava and coworkers [12] synthesized and studied the antiinflammatory activity of some 3-(O-substituted phenyl)-4-substituted phenyl-5-alkyl/alkenyl mercapto-1H-1,2,4-triazoles. The compound 2,4dihydro-1,2,4-triazole-3-thiones was prepared and used as bactericides, fungicides, and pesticides [13]. Insecticidal and ascaricidal properties of 4-methyl-3-(trifluoromethyl)- $\Delta^{2}$-1,2,4-triazoline-5-thiones were also reported [14]. A series of 3-(2,4-dichlorophenyl)-4-aryl-5-mercapto-1,2,4triazoles compounds possess good fungitoxic properties [15]. Several 3-aryloxy methyl-1,2,4-triazoles have been synthesized and screened for their antifungal activities [16].

A survey on the triazole derivatives reveals that these compounds possess biological activities, and the synthetic utility of substituted groups depend on their stereochemistry. To understand the conformation and packing features of the compounds, the crystal structure determination of these triazole derivatives was carried out. The chemical diagrams of 3-Phenyl-4-amino-5-mercapto-1,2,4-triazole (PAMT) and 3(4-Methylphenyl)-4-amino-5-mercapto-1,2,4-triazole (MAMT) are shown in Figure 1.
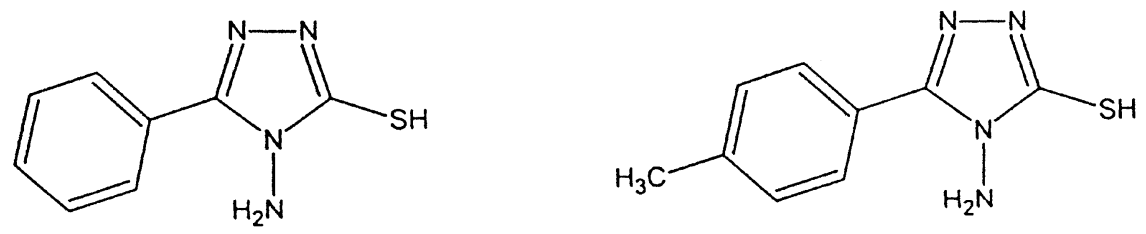

FIGURE 1 Chemical diagrams of PAMT and MAMT. 


\section{X-RAY DATA COLLECTION, STRUCTURE SOLUTION, AND REFINEMENT}

\section{Data Collection}

Intensity data were collected from a Siemens SMART CCD [17] area detector diffractometer with graphite monochromated MoK $\alpha$ radiation for PAMT. The entire data collection was covered over a hemisphere of reciprocal space by a combination of three sets of exposures, each having a different $\phi$ angle $\left(0,88\right.$, and $\left.180^{\circ}\right)$ for the crystal, and each exposure time of $10 \mathrm{~s}$ covered $0.3^{\circ}$ in $\omega$. The crystal-to-detector distance was $4 \mathrm{~cm}$ and the detector swing angle was $-35^{\circ}$. Data was complete by over $99 \%$. Crystal decay, monitored by repeating thirty initial frames at the end of the data collection and analyzing the duplicate reflections, was found to be negligible.

For MAMT, the data were collected on a CAD4 diffractometer [18] using graphite monochromated $\mathrm{CuK} \alpha$ radiation. Accurate unit cell parameters were derived from least-squares analysis using 25 reflections. In order to check the intensity deterioration due to the radiation or crystal degradation, three standard reflections were monitored for every $1 \mathrm{~h}$ and for every hundred reflections.

Both the structures were solved using direct methods in SHELXS 97 [19] and refined in SHELXL97 [20]. The nonhydrogen atoms were treated with anisotropic thermal parameters. Hydrogen atoms were fixed at chemically acceptable positions but not refined. The geometrical parameters were calculated using PARST [21], and the molecular graphics were drawn through ZORTEP [22].

\section{RESULTS AND DISCUSSION}

The crystal and refinement data are given in Table I. Figures 2 and 3 show the ZORTEP plot of the molecules of PAMT and MAMT with thermal ellipsoids at $30 \%$ probability level.

The bond lengths and bond angles of PAMT and MAMT are comparable with the values reported in the literature [23]. The bonds N2-C3 (1.308(5); $1.312(3) \AA$ ) and N1-C5 (1.338(5); 1.341(3) A) show double bond character. The other $\mathrm{N}-\mathrm{C}$ bonds in both the structures assume intermediate character, indicating the delocalization of the electron cloud. The bond lengths $(\mathrm{C} 5-\mathrm{S} 13=) 1.668(4) \AA$ in PAMT and $1.675(3) \AA$ in MAMT are shorter than the reported values [24] due to the zwitterionic from (Figure 4).

The least-squares plane calculation shows that the triazole rings are planar and the atoms N12 \& S13 also lie in the plane of the ring in both the 
TABLE I Crystal Data for PAMT and MAMT

\begin{tabular}{|c|c|c|}
\hline Parameters & PAMT & MAMT \\
\hline Empirical formula & $\mathrm{C}_{8} \mathrm{H}_{8} \mathrm{~N}_{4} \mathrm{~S}$ & $\mathrm{C}_{9} \mathrm{H}_{10} \mathrm{~N}_{4} \mathrm{~S}$ \\
\hline Formula weight & 192.24 & 206.27 \\
\hline Temperature (K) & $293(2)$ & $293(2)$ \\
\hline Wavelength & $0.71073 \AA$ & $1.5418 \AA$ \\
\hline Crystal system & Triclinic & Triclinic \\
\hline Space group & $\mathrm{P} \overline{1}$ & $\mathrm{P} \overline{1}$ \\
\hline \multirow[t]{6}{*}{ Unit cell dimensions } & $\mathrm{a}=6.1698(3) \AA$ & $\mathrm{a}=5.996(1) \AA$ \\
\hline & $\mathrm{b}=7.1765(1) \AA$ & $\mathrm{b}=7.582(2) \AA$ \\
\hline & $\mathrm{c}=9.9894(3) \AA$ & $\mathrm{c}=11.143(1) \AA$ \\
\hline & $\alpha=81.87(1)^{\circ}$ & $\alpha=73.16(1)^{\circ}$ \\
\hline & $\beta=84.97(2)^{\circ}$ & $\beta=89.65(1)^{\circ}$ \\
\hline & $\gamma=78.81(2)^{\circ}$ & $\gamma=87.88(1)^{\circ}$ \\
\hline Volume & $428.72(3) \AA^{3}$ & $484.52(3) \AA^{3}$ \\
\hline Z & 2 & 2 \\
\hline Calculated density & $1.489 \mathrm{Mg} / \mathrm{m}^{3}$ & $1.414 \mathrm{Mg} / \mathrm{m}^{3}$ \\
\hline Absorption coefficient & $0.330 \mathrm{~mm}^{-1}$ & $2.674 \mathrm{~mm}^{-1}$ \\
\hline $\mathrm{F}(000)$ & 200 & 216 \\
\hline Crystal size & $0.16 \times 0.10 \times 0.04 \mathrm{~mm}$ & $0.25 \times 0.30 \times 0.08 \mathrm{~mm}$ \\
\hline$\theta$-range for data collection & 2.06 to $25.99^{\circ}$ & 4.15 to $72.41^{\circ}$ \\
\hline \multirow[t]{3}{*}{ Index ranges } & $-7 \leq h \leq 7$ & $-7 \leq h \leq 7$ \\
\hline & $-5 \leq \mathrm{k} \leq 8$ & $0 \leq \mathrm{k} \leq 9$ \\
\hline & $-11 \leq 1 \leq 12$ & $-13 \leq 1 \leq 13$ \\
\hline Reflections collected & 2672 & $207 \overline{7}$ \\
\hline Independent reflections & $1655[$ R(int $)=0.0479]$ & $1921[\mathrm{R}(\mathrm{int})=0.0749]$ \\
\hline $\begin{array}{l}\text { Observed reflections } \\
\qquad[\mathrm{I}>2 \sigma(\mathrm{I})]\end{array}$ & 1087 & 1684 \\
\hline Refinement method & $\begin{array}{l}\text { Full-matrix least-squares } \\
\text { on } \mathrm{F}^{2}\end{array}$ & $\begin{array}{l}\text { Full-matrix least-squares } \\
\text { on } \mathrm{F}^{2}\end{array}$ \\
\hline Goodness of fit on $\mathrm{F}^{2}$ & 1.002 & 1.048 \\
\hline Final R-indices $[\mathrm{I}>2 \sigma(\mathrm{I})]$ & $\mathrm{R}_{1}=0.0871, \mathrm{wR}_{2}=0.2170$ & $\mathrm{R}_{1}=0.0656, \mathrm{wR}_{2}=0.1820$ \\
\hline
\end{tabular}

molecules. The phenyl ring is planar (maximum deviation is 0.009(5) $\AA$ for atom C9) and lies slightly out of plane of the triazole ring in MAMT, whereas the ring in PAMT lies in the plane of the triazole ring. The corresponding orientation angles subtended by phenyl and triazole groups in MAMT and PAMT are $5.7(1)^{\circ}$ and $1.4(2)^{\circ}$, respectively. The substituted methyl group $\mathrm{C} 14$ also lies in the plane of the phenyl ring (deviation: $0.007(4) \AA)$. The exocyclic bond angles, $(\mathrm{C} 10-\mathrm{C} 9-\mathrm{C} 14=) 122.1(3)^{\circ}$ and $(\mathrm{C} 8-\mathrm{C} 9-\mathrm{C} 14=) 121.3(3)^{\circ}$, show slight variation from the normal value of $120^{\circ}$. The bond angles involving atoms N4-C3-C6 (127.1(3) for PAMT and $128.3(2)^{\circ}$ for MAMT) and N2-C3-C6(123.0(3) ${ }^{\circ}$ for PAMT and $122.2(2)^{\circ}$ for MAMT) are expanded and contracted due to the steric hindrance between N12 and phenyl group. 


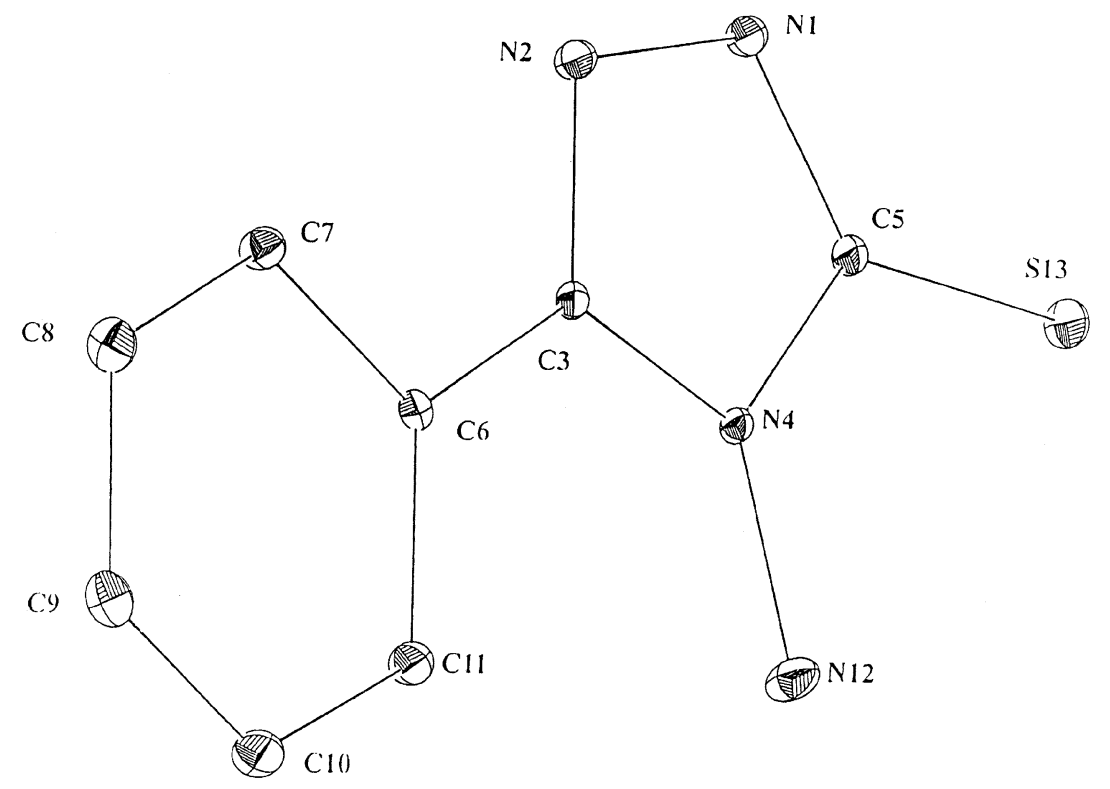

FIGURE 2 ZORTEP diagram of PAMT.

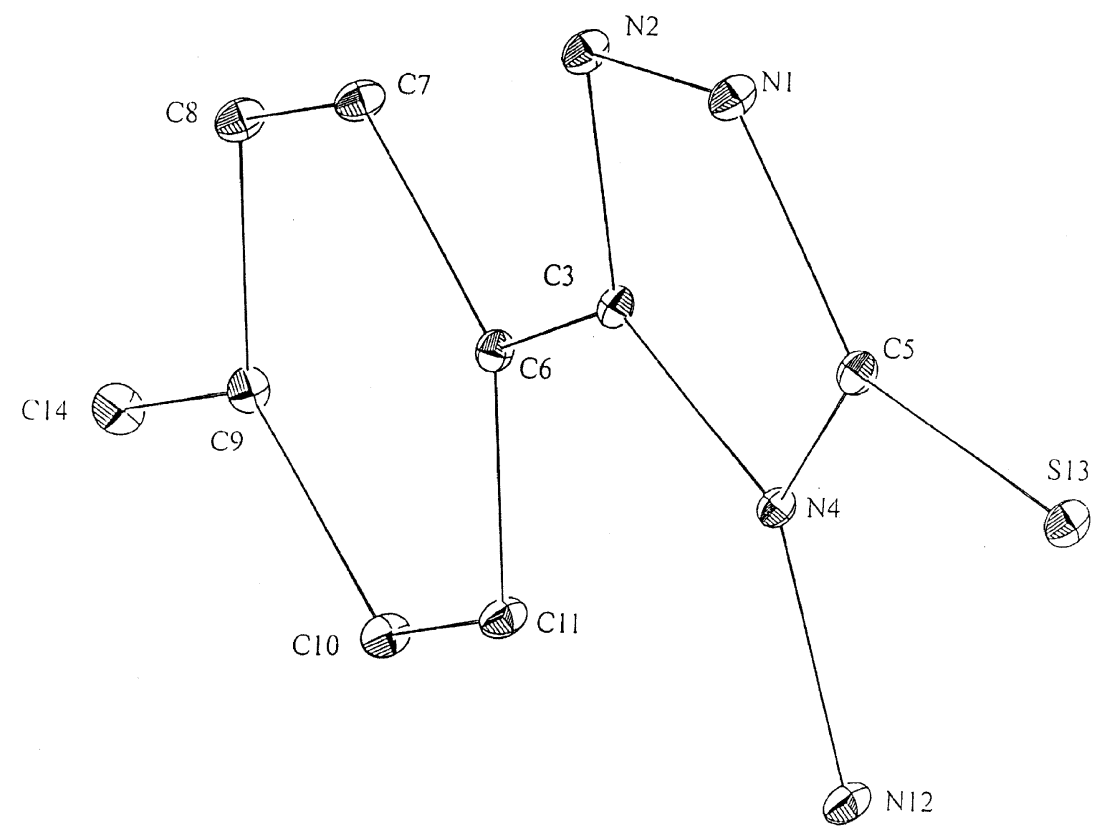

FIGURE 3 ZORTEP diagram of MAMT. 

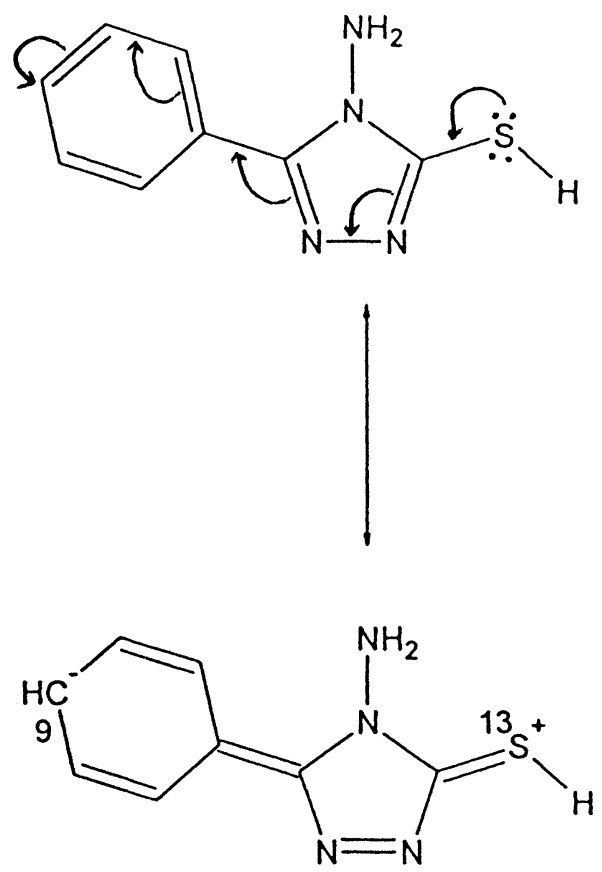

FIGURE 4 Zwitterionic formation in PAMT and MAMT.

Interestingly, the translationally related molecules along a direction form hydrogen bonds N12-H12A...N2 $(\mathrm{x}+1, \quad \mathrm{y}, \quad \mathrm{z})$ for PAMT and N12-H12A ... N2 $(\mathrm{x}-1, \mathrm{y}, \mathrm{z})$ for MAMT. The details are: PAMT: $\mathrm{N} 12 \ldots \mathrm{N} 2=3.161(6) \AA$, and $\mathrm{N} 12-12 \mathrm{~A} \ldots \mathrm{N} 2=122.3(3)^{\circ} . \quad$ MAMT: $\mathrm{N} 12 \ldots \mathrm{N} 2=3.206(3) \AA$, and N12-H12A $\ldots \mathrm{N} 2=119.0(2)^{\circ}$.

\section{PREPARATION OF PAMT AND MAMT}

The values mentioned in square brackets correspond to the sample MAMT.

A mixture of potassium salt of $\beta$-aryldithiocarbazinate $(0.1 \mathrm{~mol}$, $25.0 \mathrm{~g})[0.1 \mathrm{~mol}, 26.4 \mathrm{~g}]$ and hydrazinen hydrate $(80 \%, 0.25 \mathrm{~mol}, 12.5 \mathrm{ml})$ $\left[80 \%, 0.25 \mathrm{ml}, 12.5 \mathrm{ml}\right.$ ] was heated on an oil-bath at $150^{\circ} \mathrm{C}$ for $5 \mathrm{~h}$ (evolution of $\mathrm{H}_{2} \mathrm{~S}$ gas). The reaction mixture was then cooled and poured into cold water $(130 \mathrm{ml})[200 \mathrm{ml}]$, acidified with conc. $\mathrm{HCl}$, filtered, washed with cold water $(2 \times 50 \mathrm{ml})[3 \times 250 \mathrm{ml}]$ and recrystallized from aqueous ethanol to get the product in $83 \%[90 \%]$ yield. 


\section{REFERENCES}

[1] Bradbury, R. H. \& Rivett, J. E. (1991). J. Med. Chem., 34, 15.

[2] Hirota, T., Sasaki, K., Yamamoto, T., \& Nakayama, T. (1991). J. Heterocycl. Chem., 28, 257.

[3] Wasler, A., Flynn, T., \& Mason, C. (1991). J. Heterocycl. Chem., 28, 1221.

[4] Garcia, Y., Van Koninsbruggen, P. J., Codjovi, E., Lapouyade, R., Khan, O., \& Rabardel, L. (1997). J. Mater. Chem., 7, 857.

[5] Khan, O. \& Martinez, C. J. (1998). Science, 279, 44.

[6] Heindel, N. D. \& Reid, J. R. (1980). J. Heterocycl. Chem., 17, 1087.

[7] Vreugdenhil, W., Haasnoot, J. G., \& Reedijik, J. (1987). Inorg. Chim. Acta., 129, 205.

[8] Albada, G. A., Van de Graaff, R. A. G., Haasnott, J. G., \& Reedijik, J. (1984). Inorg. Chem., 23, 1404.

[9] Vos, G., Ie Febre, R. A., Van de Graaff, R. A. G., Haasnott, J. G., \& Reedijik, J. (1983). J. Am. Chem. Soc., 105, 1682.

[10] Mazzone, G., Bonina, F., Panico, A. M., Amico-Roxas, M., Caruso, A., Blandino, G., Vanella, A. (1987). Farmaco Ed. Sci., 42, 525.

[11] Massa, S., Di Santo, R., Retico, A., Artico, M., Simonetti, N., Fabrizi, G., \& Lamba, D. (1992). Eur. J. Med. Chem., 27, 495.

[12] Bhargava, K. P., Tandon, M., \& Bhalla, T. N. (1981). Indian. J. Chem., 20B, 1017.

[13] Milcent, R. \& Malbec, F. (1985). Chemical Abstracts, 103, 104977k.

[14] Cebalo, T. (1971). Chemical Abstracts, 74, 76428u.

[15] Goswami, B. N., Kataky, J. C. S., \& Boruah, J. N. (1984). Indian Chem. Soc., 61, 530.

[16] Bano, Q., Tiwari, N., Giri, S., \& Nizamuddin. (1992). Indian J. Chem., $31 B, 714$.

[17] Siemens. (1996). SMART Software Reference Manual, (Madison, WI: Siemens Analytical X-ray Instruments Inc.).

[18] Enraf-Nonius. (1994). CAD-4 EXPRESS Software, (Delft, The Netherlands: Enraf-Nonius).

[19] Sheldrick, G. M. (1997). SHELXS97. Program for the Crystal Structure Solution, (Germany: University of Gottingen).

[20] Sheldrick, G. M. (1997). SHELXL97. Program for the Crystal Structure Refinement, (Germany: University of Gottingen).

[21] Nardelli, M. (1983). Comput. Chem., 7, 95.

[22] Zsolnai, L. (1997). ZORTEP, An Interactive Graphics Crystal Structure Illustrations, (Germany: University of Heidelberg).

[23] Chinnakali, K., Fun, H. K., Razak, I. A., Murugan, P., \& Ramakrishnan, V. T. (1998). Acta Cryst., C54, 781.

[24] Allen, F. H., Kennard, O., Watson, D. G., Brummer, L., Orpen, A. G., \& Taylor, R. (1987). J. Chem. Soc. Perkin Trans., II, S1-S19. 